УДК 347.447.54:336.71

\title{
С.О. Погрібний
}

\section{ПРО ПРАВОВУ ПРИРОДУ ЗОБОВ'ЯЗАНЬ ГАРАНТА ЗА БАНКІВСЬКОЮ ГАРАНТІЄЮЮ}

Динаміка економічних перетворень в Україні останніх десятиліть привела до поширення застосування в практиці економічного обороту такого загальновідомого та широковживаного на Заході інституту, як банківська гарантія. Відсутність такого правового інституту у попередньому законодавстві (за змістом та природою, а не назвою) через його абсолютну непритаманність плановій радянській економіці спричинила виникнення численних труднощів у його застосуванні на практиці в умовах сучасної української правової та економічної дійсності після запровадження цього інституту Цивільним кодексом України в 2004 році.

İ хоча забезпечувальні заходи, в тому числі й гарантія, почали застосовуватися задовго до 2008 року, особливої актуальності цей інститут набув саме у стресових випробуваннях з настанням світової фінансової кризи, яка не оминула й Україну.

До обставин, що спричиняють актуальність досліджень з обраної тематики, додалися правові проблеми відсутності в українському законодавстві загальноцивілістичного визначення категорії «гарантія», яка й політиками, й економістами, й правниками вживається почасти без єдиного розуміння, з різним змістовим навантаженням та стосовно досить різних правових явищ.

У розвинутих правових порядках, хоча й не виключається наявність проблем та суперечностей у розумінні досліджуваного інституту, погляди не вирізняються великим розходженням. Зокрема в німецькому праві міститься загальне визначення договору гарантії, за яким (стосовно якого не вимагається дотримання певної форми) гарант зобов'язується перед отримувачем гарантії відносно настання у майбутньому деяких певних наслідків (результату). Сучасне вчення про договір гарантії в Німеччині грунтується на дослідженнях Штаммлера, який бачить джерела сучасного договору гарантії в римському promissio indemnitatis, 
в якому сторона, яка обіцяє, для того, щоб прийняти ризики, могла встановити власне незалежне зобов'язання. Цим promissio indemnitatis істотно відрізняється від інтерцесії, при якій інтерцедент приймає на себе чуже зобов'язання (борг) [1, с. 163-164].

Втім повернемося до України зі зверненням, в першу чергу, до питання про поняття та правову природу банківської гарантії за чинним законодавством.

\section{Поняття та правова природа банківської гарантії}

Визначення банківської гарантії, що міститься в ст. 560 ЦК України, з врахуванням положень § 4 глави 49 цього Кодексу, дає підстави для дачі наступного поняття такої гарантії: в силу гарантії банк, інша фінансова установа, страхова організація (які у таких відносинах іменуються як гарант) на прохання іншої особи (йменованої - принципал) дають письмове зобов'язання (у майбутньому) сплатити кредиторові принципала (який іменується бенефіціар) у відповідності з умовами виданого гарантом зобов'язання грошову суму за поданням бенефіціаром письмової вимоги про іiі сплату.

Правовою формою відносин з банківської гарантії $€$ грошова вимога бенефіціара до гаранта, якій кореспондує зобов'язання останнього задовольнити цю вимогу за умови іiі пред’явлення у письмовій формі з викладом сутності допущеного принципалом порушення забезпеченого зобов'язання з поданням вказаних в гарантії документів [2, с. 202].

Гарантія являє собою своєрідний оригінальний спосіб забезпечення виконання зобов'язань.

Головною юридичною (специчічною) ознакою (банківської) гарантї як забезпечувального правочину є відсутність акцесорності, тобто незалежність гарантії від основного зобов'язання, на забезпечення якого ї видано.

Ця ознака означає, що гарантія:

1) не припиняється 3 припиненням основного зобов'язання та не змінюється 3 його зміною;

2) не стає недійсною в разі недійсності основного зобов’язання, що забезпечується нею;

3) не дає гаранту права посилатися при пред'явленні йому вимоги бенефіціаром на заперечення, що пов'язані із зобов'язанням, що забезпечується;

4) не ставить дійсність зобов'язання гаранта перед бенефіціаром у залежність від будь-яких вимог або заперечень принципала, які грунтуються на відносинах принципала з гарантом або бенефіціаром;

5) встановлює, що зобов'язання гаранта зі сплати грошей повинно бути виконано при повторній вимозі бенефіціара навіть у випадку, коли зобов'язання, яке забезпечено банківською гарантією, повністю або частково вже виконано, припинилося за іншими підставами або є недійсним [3, с. 103]. 


\section{Характер обов'язків гаранта перед бенефіціаром}

В абзаці другому частини першої статті 560 ЦК України мова йде про умови, за яких гарант відповідає перед бенефіціаром (додатково: ст. ст. 563 та 564 ЦК). При цьому застосування в першій статті параграфу 4 «Гарантія» дієслова «відповідає» дає привід дослідникам однозначно визначати відносини, що виникають між гарантом та бенефіціаром, як застосування цивільно-правової відповідальності. Стосовно необгрунтованості такого визначення скажемо далі.

Проте спочатку скористаємося логікою такого підходу до визначення обов'язків гаранта через категорію відповідальності. Отже, правова природа відповідальності гаранта часто розуміється як солідарна або субсидіарна. Втім з цим погодитися також не можна через відсутність підстав для такого.

Відповідно до ч. 1 ст. 543 ЦК України у разі солідарного обов'язку боржників (солідарних боржників) кредитор має право вимагати виконання обов'язку частково або в повному обсязі як від усіх боржників разом, так і від будь-кого з них окремо.

В силу гарантії кредитор за основним зобов'язанням вправі вимагати виконання обов'язку від боржника (принципала), до гаранта він має право пред'явити вимогу про виконання грошового зобов'язання в разі порушення зобов'язання боржником (абз. 2 ст. 560 ЦК). При цьому від гаранта можна вимагати виконання не будь-якого за своїм характером та природою зобов'язання, а лише грошового, навіть в тому випадку, якщо предметом зобов'язання принципала перед бенефіціаром $\epsilon$ не сплата грошової суми, а передача товару, виконання робіт або надання послуг.

Підкреслимо, що якщо серед умов гарантії не зазначено інше, бенефіціар вправі звернутися до гаранта про виконання грошового обов'язку без попереднього звернення до принципала.

Якщо ж вважати гаранта солідарним боржником разом із принципалом, то бенефіціар вправі був би звертатися за виконанням, наприклад, зобов'язання передати індивідуально-визначену річ як до принципала, так і до гаранта. Це, зрозуміло, не відповідає природі гарантії, діяльність з надання якої здійснюється переважно банками як спеціалізованими фінансовими установами.

В силу ч. 2 ст. 543 ЦК солідарні боржники залишаються зобов'язаними, допоки їхній обов'язок не буде виконаний у повному обсязі.

Зобов'язання гаранта перед бенефіціаром обмежується сумою гарантії, а сплата кредиторові суми, на яку видано гарантію, припиняє зобов'язання гаранта перед кредитором (ч. 1 ст. 563, п. 1 ч. 1 ст. 568 ЦК).

Обов'язок гаранта також не $є$ видом субсидіарної відповідальності. Так, у відповідності до ч. 2 ст. 619 ЦК України до пред'явлення вимоги особі, яка несе субсидіарну відповідальність, кредитор повинен пред'явити вимогу до основного боржника. Якщо основний боржник відмовив- 
ся задовольнити вимогу кредитора або кредитор не одержав від нього в розумний строк відповіді на пред'явлену вимогу, кредитор може пред’явити вимогу в повному обсязі до особи, яка несе субсидіарну відповідальність.

На відміну від наведеного правила, гарант не вправі вимагати в якості умови для задоволення вимоги бенефіціара його попереднього звернення щодо належного виконання свого зобов'язання до принципала, якщо такої умови не вказано в самій гарантії. Лише посилання кредитора на порушення боржником зобов'язання, за умови надання ним вказаних в гарантії документів, має правове значення та $є є$ єиною підставою для задоволення вимог гарантом.

Гарант відповідає перед бенефіцаром в силу правових причин, що не надто залежать від основного зобов'язання, забезпеченого цією гарантією.

Наведене дозволяє заперечити визначення зобов'язань гаранma $i$ як солідарної, $і$ як субсидіарної відповідальності. Обов'язок гаранта зазнати дію негативних факторів через вимоги бенефіціара не може бути охарактеризований й як відповідальність без вини, оскільки категорія вини, так само як й інші елементи цивільно-правової відповідальності, не мають в такому випадку правового значення для задоволення вимог кредитора в разі настання гарантійного випадку.

\section{Незалежність гарантії від основного зобов'язання}

Питання правового зв'язку між основним зобов'язанням та гарантією (якою забезпечується виконання основного зобов'язання) є одним із найскладніших, воно не має однозначного вирішення ані в науці, ані на практиці.

Відповідно до ст. 562 ЦК зобов'язання гаранта перед кредитором (бенефіціаром) не залежить від основного зобов'язання, яке забезпечене цією гарантією, зокрема і тоді, коли в самій гарантії міститься посилання на основне зобов'язання. При цьому у зазначеній статті визначено критерії такої незалежності — незалежність гарантії від припинення основного зобов'язання або його недійсності.

Цією специфічною ознакою гарантія відрізняється від інших видів забезпечення виконання зобов'язання, що містяться в главі 49 ЦК України. 3 огляду на це на відносини з видачі гарантії не поширюється загальне правило параграфа 1 глави 49 ЦК України (Загальні положення про забезпечення виконання зобов'язань), зокрема й ч. 2 ст. 548, за якою недійсне зобов'язання не підлягає забезпеченню, а також недійсність основного зобов’язання (вимоги) спричиняє недійсність правочину щодо його забезпечення, якщо інше не встановлено цим Кодексом.

Відповідно до ст. 2b Уніфікованих правил Міжнародної Торгової Палати для гарантій за першою вимогою 1992 року (Публікація МТП № 458) гарантія за своєю природою $€$ самостійною угодою, яка $€$ не- 
залежною від основного контракту чи тендеру, на яких вона грунтується, тому гарант жодним чином не зв'язаний таким контрактом або тендером, хоча б посилання на них містилося в тексті гарантії. Обов'язок гаранта - сплатити грошову суму, вказану в гарантії, з представленням письмової вимоги сплатити та інших документів, вказаних в гарантії, які за зовнішніми ознаками відповідають умовам, що описані у гарантії.

Показовим є такий приклад із судової практики: принциипал просив визнати гарантію недійсною, посилаючись на те, щз вона була видана для забезпечення неіснуючого зобов'язання. Така позиція не знайшла своєї підтримки під час розгляду справи у Вищому господарському суді України, на думку якого, відповідно до умов гарантії платіж гаранта взагалі не пов'язаний з будь-яким контрактом. Рішення у вказаній справі свідчить, що суди при розгляді справи не заперечували відносно відсутності в тексті гарантії посилань на конкретні контракти, а отже зроблено акиент на моменті незалежності гарантії як способу забезпечення від основного зобов'язання [4, с. 607-608].

В науковій літературі відзначено, що однією з особливостей гарантії, що вирізняє іiі з кола усіх інших способів забезпечення виконання зобов’язань, є незалежність гарантії від основного зобов'язання. Можна констатувати практично повну відсутність будь-якого зв'язку між зобов'язанням гаранта сплатити відповідну суму бенефіціару та основним зобов'язанням, що забезпечено гарантією [5, с. 593].

Цей принцип, що набув визначення незалежності гарантії від основного зобов'язання, знайшов свою реалізацію в Уніфікованих правилах по договірних гарантіях (редакція 1978 року, публікація Міжнародної Торгової Палати № 325) [6]. Відповідно до ст. 3.2 цих Уніфікованих правил сума зобов'язання, вказана в гарантії, не може бути скорочена (зменшена) з причини часткового виконання контракту, якщо тільки це спеціально не передбачено в гарантії.

\section{Правові наслідки порушення боржником зобов'язання, забезпече- ного гарантією}

У контексті обраної теми цієї роботи особливої актуальності набуває питання про те, якими $є$ правові наслідки порушення боржником зобов'язання, забезпеченого гарантією.

Відповідно до ч. 1 ст. 563 ЦК України у разі порушення боржником зобов’язання, забезпеченого гарантією, гарант зобов'язаний сплатити кредиторові грошову суму відповідно до умов гарантії. Це правило органічно розвиває положення абз. 2 ч. 1 ст. 560 ЦК України про те, що гарант відповідає лише за порушення зобов'язання боржником. Реалізуючи загальні положення про гарантію та на відміну від, зокрема, поруки, у наведеному правилі йдеться про те, що гарант відповідає, в разі порушення зобов'язання принципалом, - на умовах, визначених самою 
гарантією. Умови гарантії включають строк дії гарантії, максимальний розмір гарантійної суми, порядок задоволення вимог бенефіціара та інші.

Платіжні гарантії відрізняються від документарних акредитивів тим, що їх застосовують тільки в тому випадку, якщо принципал не виконав свої обов'язки. Втім гарант так само, як й емітент документарного акредитива, має справу не з фактом невиконання зобов'язання, а лише 3 документами. Правило про необхідність вказівки у вимозі бенефіціара факту та характеру порушення зобов'язання не покладає на банк (гаранта) обов'язки з перевірки цього факту. По суті ця вимога спрямована на забезпечення можливості для принцииала (виділено нами. - С. П.), якому в разі виплати гарант направляє надані йому документи, встановити факт обгрунтованості або необгрунтованості вимоги про виплату й в разі необхідності - вжити заходи по відношенню до бенефіціара [7, с. 190].

У судовій практиці також звертається увага на те, що правовою підставою для задоволення вимоги бенфіціара $€$ належним чином оформлена вимога, до якої мають бути додані передбачені в гарантії документи. В якості прикладу, з моментом виставлення кредитором у основному зобов'язанні претензії (вимоги) може бути пов'язаний момент виконання гарантійного зобов'язання гарантом.

3 метою проілюструвати правовий зв'язок між порушенням боржником зобов'язання, забезпеченого гарантією, та встановленням підстав для задоволення гарантом вимоги бенефіціара наведемо приклад постанови Вищого господарського суду України від 21 березня 2011 року № 8/351 [8].

Зміст цитованого рішення звертає на себе увагу тим, що під час оцінки обставин наведеної судової справи та встановлення підстав для задоволення гарантом вимоги бенефіціара не досліджувалося питання про наявність підстав для відповідальності принципала перед бенефіціаром у основному зобов'язанні, а також не доводилося саме порушення цього зобов'язання.

Таким чином, обов'язок гаранта є безумовним та не залежить від причин невиконання ним свого зобов'язання перед бенефіціаром. Отже навіть в тому випадку, якщо принципал не виконав свого зобов'язання внаслідок випадку або непереборної сили, що за загальних правил ст. 617 ЦК України є підставою для звільнення від відповідальності, гарант зобов'язаний задовольнити вимогу кредитора, окрім випадків, коли про інше $€$ застереження серед умов самої гарантії.

\section{Порядок пред’явлення вимоги бенефіціара до гаранта про сплату грошової суми}

Відповідно до ст. 20 Уніфікованих правил 1992 року [9] будь-яка платіжна вимога повинна бути складена в письмовій формі в доповнення до документів, визначених в самій гарантії, та повинна включати пись- 
мову заяву, яка знаходиться або в самому тексті вимоги, або в певних документах.

Письмова заява повинна містити:

1) твердження, що принципал порушив свої обов'язки за основним контрактом, а в разі тендерної гарантії - умови тендеру, а також

2) зобов'язання, які порушив принципал.

Порядок прийняття банком-резидентом (авізуючим банком) від бенефіціара вимоги щодо сплати коштів, забезпечених гарантією, визначений Положенням про порядок здійснення банками операцій за гарантіями в національній та іноземних валютах, затвердженим постановою Правління Національного банку України від 15 грудня 2004 року № 639. Згідно із п. 1 глави 2 розділу III цього Положення у разі настання гарантійного випадку і для отримання відшкодування, забезпеченого гарантією, бенефіціар може подати безпосередньо до банку-гаранта або до банку-резидента (залежно від того, як це визначено умовами гарантії) вимогу для отримання відшкодування, забезпеченого гарантією, а також усі документи, передбачені умовами гарантії (якщо таке подання в ній передбачено). Вимога та інші обумовлені в гарантії документи мають бути подані до банку-резидента для подальшого передавання цієї вимоги до банку-гаранта або іншого банку, від якого надійшла гарантія, протягом строку дії гарантії і способом, зазначеним у гарантії.

Вимога має складатися та подаватися бенефіціаром до банку-резидента письмово за довільною формою (у цьому разі вимога має містити відбиток печатки та підписи осіб бенефіціара, які зазначені в картці із зразками підписів і відбитка печатки) або в електронній формі за допомогою систем «клієнт - Іेнтернет - банк», «телефонний банкінг» тощо (має містити електронні цифрові підписи відповідальних осіб, які підписують вимогу на паперовому носіі).

\section{Строк пред'явлення вимоги бенефіціара до гаранта}

Правило ч. 4 ст. 563 ЦК України по суті деталізує положення ст. 561 ЦК України про строк дії гарантії. Законодавцем підкреслено позицію, за якою кредитор не вправі вимагати від гаранта виконання обов'язку після закінчення строку дії гарантії.

Цей строк $є$ преклюзивним, його закінчення призводить до припинення права, цей строк не підлягає подовженню та поновленню без згоди на то всіх сторін, що фактично слід вважати видачею нової гарантії*.

Задоволення гарантом вимоги кредитора про сплату гарантійної суми після закінчення строку дії гарантії, відповідно до ч. 2 ст. 569 ЦК України, буде підставою для втрати гарантом права на зворотну вимогу до принципала (додатково: ст. 561 ЦК).

\section{Межі здійснення обов'язку гаранта}

Межі обов'язку гаранта перед кредитором визначаються в ст. 566 ЦК України: “Обов’язок гаранта перед кредитором обмежується сплатою суми, на яку видано гарантію. 
У разі порушення гарантом свого обов'язку його відповідальність перед кредитором не обмежується сумою, на яку видано гарантію, якщо інше не встановлено у гарантії».

Правило абз. 1 ст. 566 ЦК знаходиться в логічному зв'язку з нормою ч. 1 ст. 563 цього Кодексу про межі відповідальності гаранта перед кредитором. Тут йдеться про сумарну відповідальність гаранта по виданій ним гарантії. Сплата гарантом суми за вимогою кредитора згідно 3 умовами виданої ним гарантії визначає зміст власного обов'язку гаранта перед цією особою.

Кредитор не вправі вимагати сплати гарантом іншої суми, ніж та, що визначена умовами гарантії. Відтак гарант відповідає лише за факт порушення боржником свого обов'язку перед кредитором. Вина сторони, доведеність такого порушення, причини його настання не впливають, якщо інше не обумовлено умовами гарантії, на межі відповідальності гаранта перед кредитором.

Проте гарант не звільняється від відповідальності за невиконання або неналежне виконання свого обов'язку перед гарантом, визначеного умовами надання гарантії.

Отже головний сенс абз. 2 ч. 1 ст. 566 ЦК полягає в тому, що правило про максимальний розмір відповідальності гаранта перед бенефіціаром не застосовується, якщо гарант порушив свій обов'язок перед кредитором, визначений умовами гарантії.

В такому випадку, за загальним правилом, відповідальність гаранта за порушення зобов'язання, що витікає з банківської гарантії, не обмежується розміром суми гарантії, якщо самою гарантією не передбачається інше. Це означає, що, знову ж таки за загальним правилом, в разі невиконання або неналежного виконання своїх зобов'язань гарант несе відповідальність в порядку та на умовах, що передбачені правилами про відповідальність за порушення зобов'язання. В цьому плані відповідальність гаранта 3 моменту спливу розумного строку (або передбаченого в гарантії) на розгляд отриманої ним вимоги бенефіціара нічим не відрізняється від відповідальності боржника за грошовим зобов'язанням. Окрім вимоги про стягнення суми, на яку видано гарантію (по суті це вимога про виконання зобов'язання в натурі), бенефіціар вправі вимагати від гаранта процентів річних на цю суму, а також частини, що не покривається відсотками, відшкодування завданих збитків. У ЦК України передбачено відшкодування збитків у ст. 623, неустойки ст. 624, якщо умови про неустойку визначатимуться умовами гарантії.

Також враховуючи, що гарантія $є$ грошовим зобов'язанням, в разі порушення гарантом свого зобов'язання мають бути застосовані положення ст. 625 ЦК України, відповідно до якої, по-перше, боржник не звільняється від відповідальності за неможливість виконання ним грошового зобов'язання; по-друге, боржник, який прострочив виконання грошового зобов'язання, на вимогу кредитора зобов'язаний сплатити суму боргу з урахуванням встановленого індексу інфляції за весь час 
прострочення, а також три проценти річних від простроченої суми, якщо інший розмір процентів не встановлений договором або законом.

Підсумуємо проведений аналіз. Виявлені особливості банківської гарантії виокремлюють цей забезпечувальний засіб з-поміж інших способів забезпечення виконання цивільно-правових зобов'язань, що дозволяє доволі умовно відносити цей засіб до його видів.

Незалежність забезпечувального зобов'язання від основного, особливий статус гаранта тощо свідчать про те, що договір гарантії досить сильно тяжіє до статусу самостійного зобов'язання, окремі ознаки якого йому вже притаманні.

Потребує критики підхід до визначення обов'язку гаранта перед бенефіціарієм як виду цивільно-правової відповідальності. Логіка законодавця, сформульована в цілому в параграфі 4 «Гарантія» та детально в ст. 566 ЦК України, свідчить про відокремлення зобов'язання (обов'язку) гаранта від його відповідальності перед кредитором. Зі змісту ст. 566 ЦК випливає, що дії гаранта, пов’язані зі сплатою суми, на яку видано гарантію, охоплюються визначенням «обов'язку гаранта». В тому випадку, якщо гарант припускає порушення свого обов'язку перед кредитором (бенефіціаром), настає відповідальність, що має конкретні правові наслідки. Правовим наслідком порушення гарантом свого обов'язку перед кредитором $є$ розширення меж самого зобов'язання, оскільки в такому випадку його відповідальність перед кредитором не обмежується сумою, на яку видано гарантію, якщо інше не встановлено у гарантії.

Слід додатково підкреслити, що вимога до гаранта не може бути поєднана як солідарна або як субсидіарна з вимогою до принципала (боржника), оскільки в законі відсутні правові підстави для такого рішення.

3 огляду на це слід критично поставитися до практики, що зустрічається, пред'явлення, як солідарної, вимоги бенефіціаром до гаранта та принципала. Підстави для пред'явлення таких позовних вимог $є$ різними: вимога до принципала грунтується на доведенні порушення останнім свого зобов'язання перед кредитором; вимога ж до гаранта випливає 3 умов виданої гарантії та, за загальним правилом, не пов'язується 3 основним зобов'язанням. Таким чином, гіпотетично, можливий спільний розгляд цих двох вимог, втім, суду і сторонам слід розуміти, що ці вимоги, як зазначалося, є різними, оскільки мають різні правові підстави та предмет. При цьому їх одночасне задоволення також можливе, проте бенефіціар має враховувати, що подвійне виконання вимоги гарантом та принципалом спричинить виникнення регресної вимоги до нього з обов’язком відшкодування завданих збитків.

\section{Пр и м і тк а}

* Відповідно до ст. 26 Уніфікованих правил 1992 року: «Если бенефициар требует продления срока действия гарантии в качестве альтернативы предъявлению платежного требования в соответствии с условиями гарантии или настоящими правилами, гарант 
должен незамедлительно информировать об этом сторону, давшую ему указание выдать гарантию. Гарант должен отложить выплату гарантийной суммы на такой срок, который бы позволил принципалу и бенефициару достичь соглашения о продлении срока действия гарантии, а принципалу — провести необходимые организационные мероприятия.

Если соглашение о продлении действия гарантии не было достигнуто в течение периода времени, указанного в предыдущем параграфе, гарант обязан выплатить гарантийную сумму бенефициару в соответствии с его платежным требованием, не прося более никаких действий с его стороны.

Гарант не несет никакой ответственности в случае, если выплата гарантийной суммы отложена на основании вышеупомянутой процедуры. Даже если принципал выразил согласие на продление срока действия гарантии, он не может быть продлен без согласия гаранта и эмитента».

\section{Л і т е р а т у р а}

1. Вебер Х. Обеспечение обязательств: пер. с нем. / Хансйорг Вебер. - М. : Волтерс Клувер, 2009. - 480 с.

2. Белов В. А. Гражданско-правовые формы отношений, направленных на обеспечение исполнения обязательств (на примере способов обеспечения, предусмотренных главой 23 Гражданского кодекса РФ) / B. A. Белов // Меры обеспечения и меры ответственности в гражданском праве: сб. ст. / рук. авт. кол. и отв. ред. М. А. Рожкова. - M. : Статут, 2010. - (Анализ современного права).

3. Российское гражданское право: учебник. В 2 т. Т. II. Обязательственное право / отв. ред. Е. А. Суханов. - 2-е изд., стереотип. - M. : Статут, 2011.

4. Договірне право України. Загальна частина : навч. посіб. / Т. В. Боднар, О. В. Дзера, Н. С. Кузнєц̧ова [та ін.] ; за ред. О. В. Дзери. - К. : Юрінком Їнтер, 2008.

5. Брагинский М. И. Договорное право. Кн. 1. Общие положения / М. И. Брагинский, B. В. Витрянский. - Изд. 2-е, испр. - М. : Статут, 1999.

6. Уніфіковані правила по договірних гарантіях (редакція 1978 року, публікація Міжнародної Торгової Палати № 325) [Електронний ресурс] // БД «Ліга: Закон Преміум». Версія 8.2.3.

7. Новоселова Л. А. Поручительство и банковская гарантия / Л. А. Новоселова // Меры обеспечения и меры ответственности в гражданском праве : сб. ст. / рук. авт. кол. и отв. ред. М. А. Рожкова. - M. : Статут, 2010. - (Анализ современного права).

8. Постанова Вищого господарського суду України від 21 березня 2011 року у справі № 8/351 [Електронний ресурс] // БД «Ліга: Закон Преміум». Версія 8.2.3.

9. Унифицированные правила Международной Торговой Палаты для гарантий по первому требованию 1992 года (публикация МТП № 458) [Електронний ресурс] // БД «Ліга: Закон Преміум». Версія 8.2.3.

\section{А нот а ція}

Погрібний С. О. Про правову природу зобов'язань гаранта за банківською гарантією. - Стаття.

Наведена стаття присвячена дослідженню питання з'ясування правової природи зобов'язань, що виникають у гаранта у цивільних відносинах з банківської гарантії. Автор визначає характер відносин учасників банківської гарантії - гаранта, принципала та бенефіціара, характер їх взаємних зобов'язань, специфіку правовідносин між ними. 3 огляду на обрану проблематику автор зосередив свою увагу на питаннях поняття та правової природи банківської гарантії, характеру обов’язків гаранта перед бенефіціаром, 
незалежності гарантії від основного зобов'язання, правових наслідках порушення боржником зобов'язання, забезпеченого гарантією, порядку пред'явлення вимоги бенефіціара до гаранта про сплату грошової суми, строку пред'явлення вимоги бенефіціара до гаранта, меж здійснення обов'язку гаранта тощо.

Ключові слова: банківська гарантія, зобов'язання гаранта, бенефіціар, принципал, межі здійснення обов'язку гаранта, незалежність гарантії від основного зобов'язання, строки пред’явлення вимоги до гаранта.

\section{А н н о т а ция}

Погребной C. A. О правовой природе обязательств гаранта по банковской гарантии. - Статья

Приведенная статья посвящена исследованию вопроса определения правовой природы обязательств, возникающих у гаранта в гражданских отношениях из банковской гарантии. Автор определяет характер отношений участников банковской гарантии гаранта, принципала и бенефициара, характер их взаимных обязательств, специфику правоотношений между ними. Принимая во внимание избранную проблематику, автор обратил свое внимание на вопросы понятия и правовой природы банковской гарантии, характера обязанностей гаранта перед бенефициаром, независимости гарантии от основного обязательства, правовых последствий нарушения должником обязательства, обеспеченного гарантией, порядка предъявления требования бенефициара к гаранту об оплате денежной суммы, сроке предъявления требования бенефициара к гаранту, пределах осуществления обязанности гаранта.

Ключевые слова: банковская гарантия, обязательство гаранта, бенефициар, принципал, пределы осуществления обязанности гаранта, независимость гарантии от основного обязательства, сроки предъявления требования к гаранту.

\section{S u m m a r y}

Pogrebnoy S. A. About legal nature of obligations of guarantor on a bank guarantee. - Article.

The Resulted article is devoted research of question of determination of legal nature of obligations, arising up for a guarantor in civil relations from a bank guarantee. An author determines character of relations of participants of bank guarantee - guarantor, principala that fide-comissary, character of their mutual obligations, specific of legal relationships between them. Having regard to select problematiku an author turned the attention on questions of concept and legal nature of bank guarantee, character of duties of guarantor before a beneficiary, to independence of guarantee from a basic obligation, law consequences of violation of obligation, provided with a guarantee a debtor, order of producing of requirement of beneficiary to the guarantor about payment of money sum, line of producing of requirement of beneficiary to the guarantor, limits of realization of duty of guarantor.

Keywords: bank guarantee, obligation of guarantor, fide-comissary, principal, limits of realization of duty of guarantor, independence of guarantee from a basic obligation, lines of producing of requirement at to the guarantor. 